\title{
DIRECTIONS TO CONTRIBUTORS
}

\section{NOTE}

Full Directions to Contributors, of which this is a summary, appear in the first (February) issue of each volume.

\section{GENERAL}

The Journal of Dairy Research publishes reports on all aspects of dairy science from any country. Material for publication should be sent to the Editor: Dr B. A. Rolls, AFRC Institute of Food Research, Earley Gate, Whiteknights Road, Reading RG6 2EF, UK. Receipt of all material will be acknowledged. Submission of a paper will be taken to imply that it reports original unpublished work, that it is not under consideration elsewhere, and that if accepted by the Journal it will not be published elsewhere in any language without the consent of the Editors. Authors of accepted articles will be asked to assign their copyright, under certain conditions, to the Journal.

\section{FORM OF PAPERS}

Papers should be written in English using the spelling of the Concise Oxford Dictionary and should as far as possible be comprehensible to the non-specialist reader. They should be concise, but without omitting necessary material, and contain sufficient detail to allow repetition of the work.

Papers should be typed with wide margins on one side of A4 or quarto paper, double spaced throughout including References, Figure legends and Table headings and footnotes. Submit a top copy and two good copies (photocopies or carbon), packed flat. A single copy will be accepted from outside Europe.

Authors should consult a recent issue of the Journal of Dairy Research to familiarize themselves with Journal conventions and layout. Attention to these and other details will speed publication.

\section{LAYOUT OF PAPERS}

The paper should generally be divided as follows. (a) Cover sheet with the title of the article, names of authors each with one forename, together with their affiliations, a shortened version of the title suitable as a heading, and the name and address for correspondence. $(b)$ A brief Summary should encapsulate the whole paper, showing clearly the new knowledge acquired. (c) The introduction, without heading, should not contain a full literature review, but should indicate why the subject of enquiry is interesting or important, and why the authors have chosen the approach described. (d) The Experimental or Materials and Methods section should contain adequate descriptions of procedures or appropriate references; sources of all materials (including address with post code) and sources or strains of animals, microorganisms and so on should be indicated. (e) Results should be as concise as possible, without repetition or inclusion of irrelevant material. Tables and illustrations should be used efficiently $(f)$ The Discussion should not repeat the results but discuss their significance. Any acknowledgements are given in a separate paragraph without heading. It is the responsibility of the authors to ensure that individuals or organizations acknowledged as providing materials or otherwise are willing to be identified. $(g)$ References. Note. For some types of paper, other divisions may be preferable.

\section{REFERENCES}

References should be given in the text as Brown \& Jones (1987) or (Schmidt, 1985; Nakamura et al. 1989); the first author with et al. is used for papers with three or more authors. Where necessary, papers are distinguished as Lenoir (1988a), (Litov et al. 1990a, b). When several references appear together in the text, cite them in chronological order, and alphabetically within years. The Reference list at the end of the paper, which should begin on a fresh page, is given in strict alphabetical order. Authors should refer to a recent issue for the format of references.

\section{TABLES}

Tables should be numbered and carry headings enabling them to be understood without reference to the text. Each Table should be typed on a separate sheet, but their approximate position in the text should be indicated. Symbols for footnotes should be in the order $\dagger, \ddagger, \S, \|$,, , $\dagger \dagger$, etc. The use of ${ }^{*}{ }^{* *}$, etc, should be limited to indicating levels of significance.

\section{ILLUSTRATIONS}

Line drawings and photographs, which must be originals, should be numbered as Figures in Arabic numerals. Drawings should each be on a separate sheet, not larger overall than those on which the paper is typed, and packed flat. Curves or lines should not extend beyond the experimental points, which should be indicated, symbols used being, in order: $O, \boldsymbol{\theta}, \Delta, \Delta, \square, \boldsymbol{\square}, \times,+$. Attached to each Figure should be a translucent flyleaf on which should be indicated clearly: title of paper and authors, Figure number, all numerals and lettering intended to appear on the final illustration, in the correct positions relative to the drawing underneath. There should be no letters or numerals on the drawing or photograph itself. Each Figure should be provided with a legend such that with the Figure it is comprehensible without reference to the text. Figure legends should be typed on a separate sheet or sheets.

Photographs should be glossy black and white prints accompanied by a legend as above. Scale bars on the photograph are preferable to magnifications in the legend. Only one copy of each illustration is required, but authors should ensure that photocopies provided with the other copies of the paper are of adequate quality to allow referees to judge their value.

\section{STATISTICAL TREATMENT}

Individual results should not normally be given. The methods of statistical analysis should be clearly described; a suitable reference is adequate. Authors should make it clear whether they are quoting (e.g.) SD or SE. Any statement that two groups of values are different should be supported by the level of significance involved, as a single or range of $P$ value: $(P=0.008)$ or $(P<0.01)$. Differences should not be claimed or implied if $P>0.05$.

\section{ETHICS OF EXPERIMENTS}

Authors are expected to adhere to the relevant codes covering human subjects and the use of animals.

\section{PROOFS}

Authors will be advised when to expect proofs, which should be returned without delay to Mrs B. Gillian Day, AFRC Institute of Food Research, Earley Gate, Whiteknights Road, Reading RG6 2EF, UK. Proofs are sent for the correction of any printer's or editorial errors, not for addition of new material or revision of the text. Excessive alteration may have to be disallowed or made at the authors' expense, and may delay publication. Order forms for offprints are sent with proofs and should be returned directly to The University Press, Cambridge. 


\section{Short Communications}

Heat treatment of milk can increase apparent fluorescent somatic cell count T. CLARKE

Mitogenic activity of hydrophobic fractions of proteose peptone from cows', ewes' and goats' milk measured with MARK 3 hybridoma culture

A. MATI, F. MOULTI-MATI, J.-M. GIRARDET, E. FOKOU, F. BELLEVILLE-NABET, P. NABET and G. LINDEN 


\section{JOURNAL OF DAIRY RESEARCH}

Volume 60 Number 3 August 1993

CONTENTS

\section{Original articles}

Influence of switch level of automatic cluster removers on milking performance and udder health

M. D. RASMUSSEN

Effect of caprine arthritis-encephalitis virus infection on milk cell count and

$N$-acetyl- $\beta$-glucosaminidase activity in dairy goats

D. P. RYAN, P. L. GREENWOOD and P. J. NICHOLLS

299-306

Bromocriptine treatment of periparturient goats: long-term suppression of prolactin and lack of effect on lactation

I. A. FORSYTH and P. D. LEE

Concentration of citrate in the mammary secretion of sows during lactogenesis II and established lactation

M. A. HOLMES and P. E. HARTMANN

Process integration study of a milk powder plant

L. J. ROBERTSON and A. J. BALDWIN

Proteolysis during storage of UHT milk: differences between whole and skim milk

R. LÓPEZ-FANDIÑO, A. OLANO, N. CORZO and M. RAMOS

Rheology of whey protein concentrate solutions as a function of concentration, temperature, $\mathrm{pH}$ and salt concentration

Q. TANG, P. A. MUNRO and O. J. MCCARTHY

Effect of heat treatment and other milk proteins on the interaction of lactoferrin

with monocytes

R. ORIA, M. ISMAIL, L. SÁNCHEZ, M. CALVO and J. H. BROCK

Numerical taxonomy of psychrotrophic bacteria isolated from raw ewes' milk

M.-R. GARCÍA-ARMESTO, M. PRIETO, C. ALONSO, M.-L. GARCÍA-LÓPEZ, M.-C. GARCÍAFERNÁNDEZ and A. OTERO

Interactions of temperate bacteriophages of Streptococcus salivarius subsp.

thermophilus with lysogenic indicators affect phage DNA restriction patterns and host ranges

B. FAYARD, M. HAEFLIGER and J.-P. ACCOLAS

Proteolytic specificity of chymosin on bovine $\alpha_{\mathrm{S} 1}$-casein

P. L. H. MCSWEENEY, N. F. OLSON, P. F. FOX, A. HEALY AND P. HØJRUP

Polyclonal antibodies with predetermined specificity against bovine $a_{\mathrm{s} 1}$-casein:

application to the detection of bovine milk in ovine milk and cheese

M.-P. ROLLAND, L. BITRI and P. BESANÇON

Growth of Listeria monocytogenes in Camembert and other soft cheeses at refrigeration temperatures

J. P. BACK, S. A. LANGFORD and R. G. KROLL

Relationships between plasmin levels in rennet caseins and proteolytic and rheological changes on storage of cheese analogues made from these caseins D. M. MULVIHILL and A. MCCARTHY

Continued inside back cover

(C) Proprietors of Journal of Dairy Research 1993 Printed in Great Britain by the University Press, Cambridge

\section{CAMBRIDGE} UNIVERSITY PRESS 